\title{
Nagy üvegképző hajlamú és nagy entrópiájú ötvözetek képződése és stabilitása
}

\section{The Formation and Stability of Bulk Amorphous and High Entropy Alloys}

\author{
Szabó Attila, ${ }^{1}$ Bán Krisztián, ${ }^{2}$ Hlinka József, ${ }^{3}$ Pásztor Judit, ${ }^{4}$ Lovas Antal ${ }^{5}$ \\ ${ }^{1}$ Dunaújvárosi Egyetem, Müszaki Intézet, Gépészeti Tanszék. Dunaújváros, Magyarország, \\ szaboattila@uniduna.hu \\ ${ }^{2}$ Budapesti Müszaki és Gazdaságtudományi Egyetem, Közlekedésmérnöki és Jármümérnöki Kar, \\ Gépjármütechnológia Tanszék, Budapest, Magyarország, krisztian.ban@gjt.bme.hu \\ ${ }^{3}$ Budapesti Müszaki és Gazdaságtudományi Egyetem, Közlekedésmérnöki és Jármümérnöki Kar, \\ Gépjármütechnológia Tanszék, Budapest, Magyarország, jozsef.hlinka@gjt.bme.hu \\ ${ }^{4}$ Sapientia Erdélyi Magyar Tudományegyetem, Marosvásárhelyi Kar, Marosvásárhely, Románia, \\ pjudit@ms.sapientia.ro \\ ${ }^{5}$ Budapesti Müszaki és Gazdaságtudományi Egyetem, Közlekedésmérnöki és Jármümérnöki Kar, \\ Gépjármütechnológia Tanszék, Budapest, Magyarország, antal.lovas@gjt.bme.hu
}

\begin{abstract}
Two kind of phase stabilization mechanism are discussed and compared: the first is characteristic of the formation of bulk amorphous alloys, in which the high supercooling ability of multicomponent liquids is responsible for the glassy phase stabilization. Here the hindered nucleation of crystalline phases is the center phenomenon. The origin of this hindering is the slowing atomic mobility in the supercooling melt. In contrast the melt supercooling is negligible during the high entropy alloy formation. It is believed that stability of crystalline single fcc phase is the consequence of the characteristic of high configurational entropy at high temperatures. However, the significance of this entropy-dominated stabilization is overestimated in several references. It has been concluded that transition metal contraction (arising from the d electron participation in the overall bonding state) does also contribute to the high temperature stability of fcc single phase in the high entropy alloys.
\end{abstract}

Keywords: bulk metallic glass, high entropy alloy.

\section{Összefoglalás}

Két ötvözetcsalád, a tömbi formában előállított amorf (BMG) és a nagy entrópiájú (HEA) ötvözetek képződési mechanizmusát és stabilitását hasonlítjuk össze jelen közleményben. Az összehasonlítás fő elve az olvadékaik túlhűlési képessége a megszilárdulás folyamatában. A BMG-ötvözetek olvadékai a különböző típusú kémiai kötések miatt nagy túlhűlési hajlamot, s ebből eredően nagy üvegképző hajlamot is mutatnak. Ennek jellemző mechanizmusa a klaszterképződés, amellyel az atommozgékonyság s így a kristálycsíra-képződés is visszaszorul. A HEA-ötvözetek olvadékai nem mutatnak ilyen hajlamot. Nagy hőmérsékleten, közvetlenül az olvadáspont környékén, az olvadékfázissal azonos összetételü, rendezetlen szilárd oldat formájában kristályosodnak. A kétféle olvadéktípusban az eltérő atomi mobilitás tükröződik az olvadékok viszkozitásának eltérő hőmérséklet-függésében is. A HEA-ötvözeteknek a konfigurációs entrópia által dominált fázisstabilitásához elektronszerkezeti tényezők is hozzájárulnak: itt szerepet kap a d-elektronok részvétele az atomok közötti kötésekben.

Kulcsszavak: tömbi formában elöállított amorfötvözetek, nagy entrópiájú ötvözetek. 


\section{Bevezetés}

Az utóbbi néhány évtized (1980-2020) metallurgiai és fémfizikai kutatásainak középpontjában a nemegyensúlyi rendszerek megismerése állott (üvegállapot, nanoszerkezetek, fémes tömbi üvegek és legújabban a nagy entrópiájú ötvözetek). Ennek oka - a szerkezetük megértésén túl - két kiemelkedő mágneses tulajdonság, a permeabilitás és a nagy telítési mágnesezettség, amelyek a fémüvegekben és a nanokristályos ötvözetekben együttesen megtalálhatók [1]. E tulajdonságok új típusú transzformátorok, elektromotorok és egyéb induktív elemek fejlesztését tették lehetővé [2, 3]. Jelenleg a kutatások két ötvözetcsoport irányába fordultak: az egyik a tömbi méretekben is nagy üvegképző hajlamú ötvözetek, illetve az utóbbi évtizedben az úgynevezett nagy entrópiájú ötvözetek családja. Mindkét ötvözetcsaládnak közös vonása, hogy számos (5-6) komponensből állnak, szemben a korábban kifejlesztett (lágymágneses célokat szolgáló) háromkomponensű, kis üvegképző hajlamú ötvözetekkel. Az utóbbi két ötvözettípust nem a mágneses jellemzők miatt, sokkal inkább az ígéretes mechanikai tulajdonságaik és korrózióállóságuk miatt fejlesztették ki [4]. A szóban forgó két ötvözettípus a képződési mechanizmusát illetően azonban lényeges különbséget mutat: a tömbi formában előállított amorf ötvözetek képződésében az olvadék túlhülési hajlama játszik döntő szerepet, a nagy entrópiájú ötvözetek ezzel szemben kristályos fázisként, egyetlen megszilárdulási lépéssel keletkeznek az azonos összetételű olvadékból, és termikus stabilitásukat a többféle komponensből adódóan a nagy konfigurációs entrópiával értelmezik. Innen ered az elnevezésük is [5]. Az utóbbi ötvözetcsalád termikus stabilitásának kutatása jelenleg is a tudományos érdeklődés középpontjában van. E két anyagcsalád képződési mechanizmusának és termikus stabilitásának összehasonlítása képezi a jelen publikáció célját is.

\section{A szakirodalmi eredmények értelme- zése}

\subsection{A nagy entrópiájú ötvözetek és tömbi formában előállított amorf ötvözetek képződési mechanizmusának összeha- sonlítása}

Mind a BMG-, mind a HEA-ötvözetek több (általában 4-5 vagy ennél több) komponensből állnak, és közvetlen megszilárdulással keletkeznek az olvadékból. Fő különbség közöttük a képződésük során lejátszódó olvadék túlhűthetőségében rejlik. E különbség olyan számottevő, hogy amíg a BMG-ötvözet amorf szerkezet formájában szilárdul meg, addig a HEA-ötvözetek megszilárdulása során egyfázisú, kristályos szerkezetű fázisok keletkeznek. Ez utóbbiak szerkezete ideális esetben fcc szilárd oldat. Ebből következően a kiinduló olvadék túlhűthetősége központi fogalom a két anyagcsalád tulajdonságainak kialakításában, illetve megkülönböztethetőségében. A túlhűthetőség elvi határai az 1. ábra alapján érthetők meg.

$\mathrm{Az}$ 1. ábra az olvadékok túlhüthetőségének elvi határát értelmezi az entrópia hőmérsékletfüggése alapján. Egy túlhűléssel és túlhűlés nélkül megszilárduló olvadék entrópiájának a hőmérsékletfüggését láthatjuk ( $T_{m}$ az egyensúlyi olvadási hőmérséklet, $T_{K}$ az ún. Kauzmann-hőmérséklet, amely alatt az olvadék állapotú anyag entrópiája kisebb lenne a kristályos állapotúénál, ami nyilván lehetetlen). Ez a $T_{K}$ hőmérséklet jelenti a túlhűthetőség elvi határát. A BMG-ötvözetek nagy túlhütéssel szilárdulnak meg az olvadék fázisból, vagyis ezeknek olvadékai nagymértékben túlhűthetőek, anélkül, hogy a kristálycsírák keletkeznének.

A fentiekkel ellentétben a HEA-ötvözetek kristályosodása nem jár jelentékeny túlhűléssel. Így szilárdulnak meg pl. a tiszta fémek vagy azok a kétkomponensű szilárd oldatok, amelyek pszeudobinér fázisdiagramjaiban a likvidusz- és szoliduszgörbe közel azonos trend szerint halad a koncentrációtengely mentén.

Az olvadékok túlhűthetőségét tehát a komponensek kémiai természete és ebből eredően a fázisdiagram alakja határozza meg. Ez utóbbi a

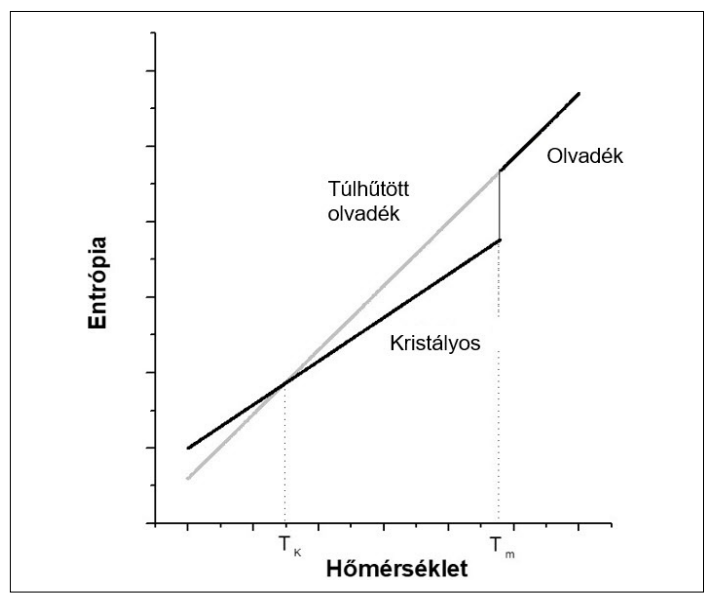

1. ábra. Az entrópia hőmérsékletfüggése szilárd és olvadékfázisban: a Kauzmann-hömérséklet jelentése [6] 
likvidusz- és a szoliduszgörbék egymáshoz viszonyított meredekségében tükröződik leginkább.

Ha a két görbe meredeksége lényegesen eltér, akkor jelentős túlhűthetőség várható. Ezért figyelhető meg jelentékeny üvegképző hajlam, pl. az eutektikumok összetételének környezetében. Jellemzően nagy túlhűlési hajlamot (és ezzel együtt jelentékeny üvegképzési hajlamot) mutatnak az átmenetifém-metalloid rendszerek (Fe-B, Fe-P, Fe-Si-B stb.). Ha a komponensek száma nagyobb (4-5), a túlhüthetőség növekszik, és az olvadék megszilárdulása a $T_{K}$ határértékhez közelít. Ekkor a lehűlő olvadékban jelentős klaszterképződésről és nagy üvegképződési hajlamról beszélünk: ezek a tömbi formában előállított amorf ötvözetek.

A viszkozitás hőmérsékletfüggése mint a makroskálán is érzékelhető jelenség tükrözi a fent tárgyalt viselkedést, hiszen ebben az ötvözetet alkotó atomok mobilitásának hőmérsékletfüggése nyilvánul meg. Ezt a kapcsolatot írja le a StokesEinstein-összefüggés,

$$
\frac{1}{\eta}=\lambda^{2} \cdot\left(\frac{A}{l \cdot k \cdot T}\right)
$$

amely kapcsolatot teremt az atomi szintű elemi elmozdulások időtartama és a viszkozitás változása között ( $A$ = állandó, $k=$ Boltzmann-állandó, $T=$ abszolút hőmérséklet, $\lambda$ és $l=$ molekulaméretű távolságok, $\eta$ = viszkozitás).

Az atomi elmozdulások frekvenciája kb. 1013 Hz az olvadáspont környezetében, ezért két szomszédos atom egymás melletti tartózkodási ideje $10^{-13} \mathrm{~s}$ az olvadáspont körüli hőmérsékleten. Ennek értelmében az azonos és különböző atomok között nem létesül tartós kapcsolat az olvadásponthoz közeli hőmérsékleten, vagyis véletlenszerű atomi elrendeződésről beszélhetünk.

A rövid távú rend az azonos és különböző atomok között kb. $\approx 2 / 3 T_{m}$ körüli hőmérsékleteken kezd kialakulni (angolul: jumming temperature) [9], és a képződő néhány atom tartós kapcsolatából álló atomcsoportosulás lokális összetétele fokozatosan közelít valamely intermetallikus vegyület összetételéhez. Ez a jelenség azért megy végbe, mert az azonos és különböző atomok közötti kötéserősség nagyobb. A klasztereken belül tehát az átlagos atomi mozgékonyság kisebb (az ún. relaxációs idő tehát nagyobb), mint a klasztereken kívüli olvadéktartományokban.

A viszkozitás hőmérsékletfüggése, illetve ennek matematikai leírása követi a fent vázolt jelenségeket. Ennek megfelelően kétféle függvénytípussal írható le a hőmérsékletfüggés:
- Arrhenius-típusú:

$\eta=A \cdot \exp \left[E /\left(T-T_{0}\right)\right]$ (strong liquid),

nagy üvegképző hajlamú olvadékok esetén,

- Vogel-Fulcher-típusú:

$$
\eta=\eta_{0} \cdot \exp \left[B /\left(T-T_{0}\right)\right] \text { ) (fragile liquid) }
$$

kis üvegképző hajlamú olvadékok esetén.

Az Arrhenius-típusú összefüggés egyetlen aktiválási energiát tételez fel a túlhűlés teljes hőmérséklet-tartományában. Ilyenek például a $\mathrm{SiO}_{2}$-típusú kovalens üvegek olvadékai, amelyekben egyetlen kötéstípus van; a teljes hőmérséklet-tartományban tehát egyetlen kötéstípus hőmérsékletfüggésével kell számolni. Ezek az úgynevezett „strong” olvadékok. Ilyen típusú olvadékokból keletkeznek a tömbi formában előállított amorf ötvözetek.

Ezzel ellentétben a $\eta(T)$ több, hőmérséklettől függő tartománnyal írható le, ha több, eltérő kötéserősségű atomi kapcsolatot tartalmaz az olvadék. Ezek az ún. fragile olvadékok (kis üvegképző hajlamú ötvözetek) (lásd 2. ábra).

A 3. ábra alapján kijelenthető, hogy a nagy üvegképző hajlamú olvadékok zöme többalkotójú (sokalkotójú) ötvözet, amelyekben a tipikus, fémes kötések mellett kovalens (erős, irányított) kötéseket jelentő atomi kapcsolatok is vannak.

Ez azt is jelenti, hogy már kis hűtési sebesség alkalmazása esetén is amorf fázis keletkezik a megszilárdulás során. Ilyen ötvözeteket tartalmaz a 4. ábra.

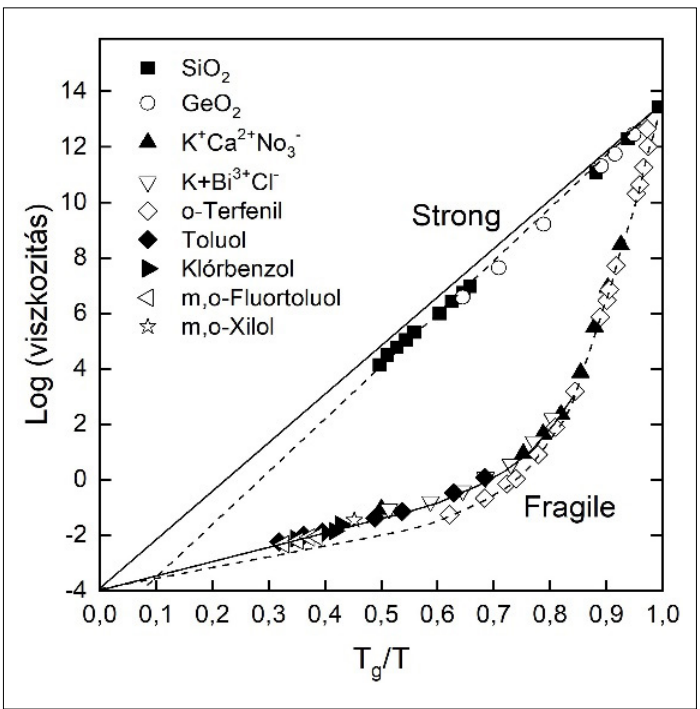

2. ábra. A viszkozitás hőmérsékletfüggésének $(\eta(T))$ összehasonlítása „strong” és „fragile” üvegképző olvadékokban [7] 


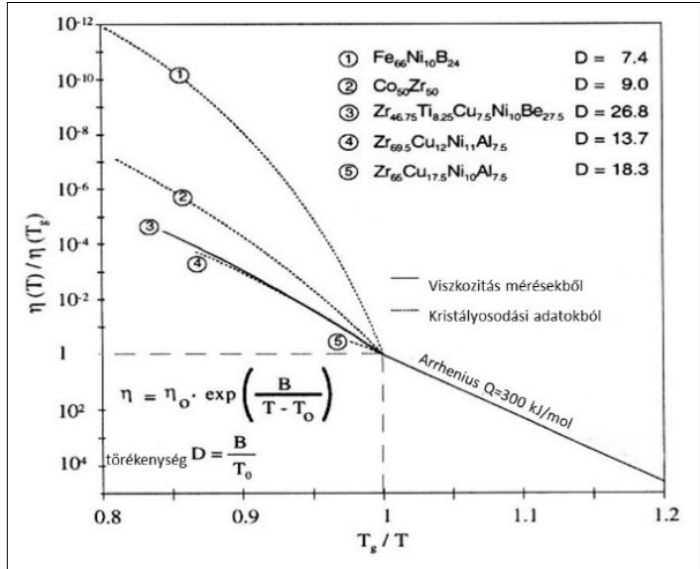

3. ábra. A viszkozitás hömérsékletfüggése különféle üvegképző hajlamú olvadékokban [8]

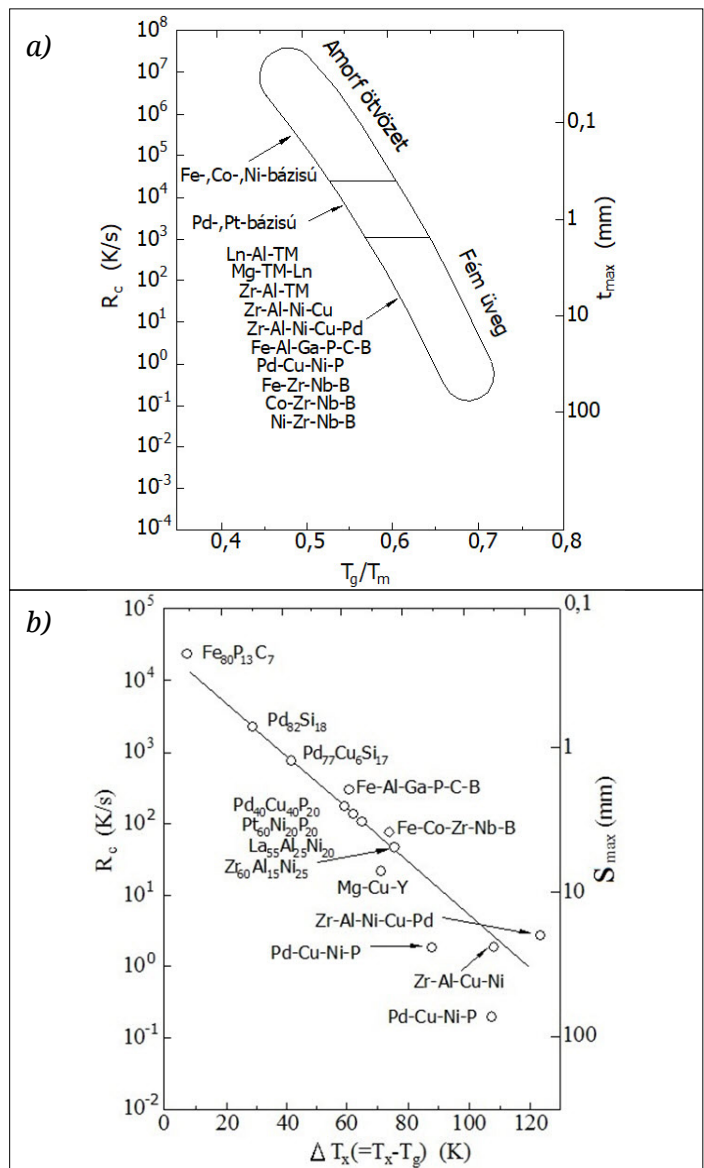

4. ábra. A kritikus hülési sebesség $\left(R_{c}\right)$ és a hozzá tartozó elérhetô maximális mintavastagság $\left(t_{\max }, S_{\text {max }}\right)$ számos nagy üvegképző hajlamú ötvözet esetén redukált üvegátalakulási hömérséklet $T_{o} / T_{m}$ (a) vagy túlhütési tartomány $\Delta T_{x}=T_{x}-T_{g}(b)$ függvényében [9]

\subsection{Klaszterképződési tendenciák az üveg- képző olvadékokban}

Az előzőekben már ismertettük, hogy az üvegképző hajlam kapcsolatban áll a hűlési folyamat során megjelenő klaszterképződési tendenciákkal [10, 11]. Feltételezések szerint a kristályos csírák képződéséhez olyan atomi átrendeződések kellenek, amelyekben az $\mathrm{A}_{\mathrm{j}} \mathrm{B}_{\mathrm{j}}$ klaszterekben részt vevő atomok is érintettek. Ezekben a flexibilis tartományokban a helyi kötőerők fékező hatása miatt lelassul a diffúziós folyamat. A klaszterek tehát kinetikai gátoltságot jelentenek a túlhülő olvadékban a kristálycsírák kialakulásánál. A klaszterek képződésének termodinamikai leírása Predel nevéhez füződik [12]. Eszerint a klaszterképző olvadékokban a teljes képződéshő a

$$
\Delta H=\Delta H^{r e g}+\Delta H_{A j B j}^{a s}
$$

kifejezéssel írható le, ahol $\Delta \mathrm{H}$ a teljes keveredési entalpia, amely kalorimetrikusan mérhető menynyiség. Ez két tagból áll: $\Delta H^{r e g}$ a reguláris oldatmodellből származó tag, $\Delta H_{A j B j}^{a s}$ pedig a néhány atom tartós kapcsolatából álló atomcsoportosulásokat alkotó atomok közötti kölcsönhatásból származik, ami az olvadéknak extra stabilitást ad a reguláris oldatokhoz képest.

A túlhűlő üvegképző oldatok szerkezete tehát a néhány atom tartós kapcsolatából álló atomcsoportosulások folyamatosan változó együtteséből és az asszociációkon kívüli atomokból áll [13]. A néhány atom tartós kapcsolatából álló atomcsoportosulások $a \approx 2 / 3 T_{m}$ hőmérséklet körül kezdenek kialakulni, és számuk, ill. összetételük fokozatosan változik a túlhülés előrehaladásával $[14,15]$. A néhány atom tartós kapcsolatából álló atomcsoportosulásokban a kötések kovalens jellegűek, ill. lokális összetételük valamely intermetallikus vegyületéhez áll közel.

A nagy üvegképző hajlamú ötvözetek olvadékait tehát a fent leírt szerkezet jellemzi.

\subsection{A nagy entrópiájú ötvözetek képződése és stabilitása}

A HEA-ötvözetek iránti fokozott érdeklődés oka azok ígéretes hőstabilitása és korróziós ellenállása. Ellentétben a tömbi formában előállított amorf ötvözetekkel, elsősorban átmeneti fémeket tartalmaznak, metalloidok nélkül. Előnyük az is, hogy készítésük sem igényel különösebb öntési technikát, pl. gyorshütést. Elnevezésük is onnan ered, hogy számos komponenst tartalmaznak, jellemzően legalább öt különböző, főként átmeneti fémet. Ezek „főkomponensként”, többnyire 
5-35\%-ban vannak jelen az ötvözetben, de adalékként egyéb fémeket is tartalmaznak, rendszerint 5\% alatti koncentrációban. Nagy stabilitásukat a sok komponensből adódóan a nagy konfigurációs entrópiának tulajdonítják, az

$$
S_{\text {mix }}=R \sum x_{i} \ln x_{i}
$$

egyenletnek megfelelően ( $x_{i}$ az i-edik komponens móltörtje). Eszerint ezen ötvözetek stabilitásában inkább a keveredési entrópia és nem az elegyedéssel járó képződési entalpia játszik döntő szerepet.

A szabadenergia $G=H-T \cdot S$, definíció egyenletének megfelelően ( $G$ a Gibbs-féle szabadenergia, $\mathrm{H}$ az entalpiaváltozás, T az abszolút hőmérséklet) a teljes szabadenergia-változásban az entalpia- és entrópiaváltozás tagjai ellentétes módon stabilizálhatják a szerkezetet: az entalpiaváltozás kisebb, az entrópiatag nagyobb hőmérsékleten stabilizálja a képződött ötvözetet. A Co-Cr-Fe-Mn-Ni ötvözetben (amelyik a legismertebb ezek közül) a $\mathrm{Ni}$, Fe és Co főkomponensek a nagyobb hőmérsékleten stabil fcc szerkezetet stabilizálják, míg a $\mathrm{Cr}$ és a Mn a bcc szerkezet kialakulásának kedvez. $\mathrm{Az}$ entrópiastabilizáló szerepét azonban egyes szerzők túlhangsúlyozottnak találják [16].

Jelenleg további kutatások folynak a fázisviszonyok pontosabb megértésére ezekben az ötvözetekben, főként az fcc jellegű egyfázisúság stabilitására vonatkozóan. Jelenleg aktivitás indult a Hume-Rothery [17] által megfogalmazott oldékonysági kritériumok újragondolásáról, ill. elektronszerkezeti ismeretek alapján történő újraértelmezéséről. Elképzelhető, hogy ez a ku-

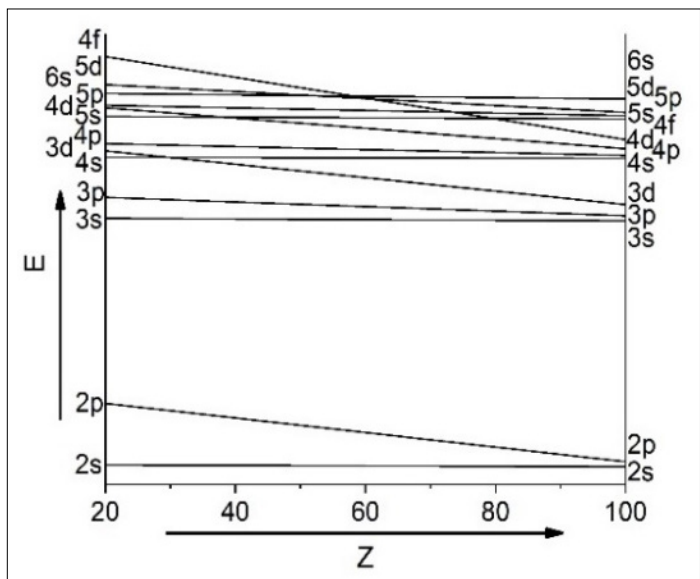

5. ábra. Az energiaszintek (ionizációs energia, E) öszszehasonlitása s-, $p$ - és d-elektronok esetében a rendszám (Z) függvényében [18] tatási célkitűzés a nagy entrópiájú ötvözetek stabilitásának megértésére is hatással lehet. Ezek a vizsgálatok rámutatnak pl. a speciális elektronszerkezetre ezekben az ötvözetekben, nevezetesen a d-elektronok hangsúlyozott jelenlétére a fémes kötésekben. Feltehetően ezt a kötésállapotot figyelembe kell venni a fázisok stabilitási viszonyainak megítélésében.

Az elemek energiaszintjeinek összehasonlítása alapján (5. ábra) láthatjuk, hogy a d-elektronok ionizációs energiája - így kötési energiája is - nagyobb az s- és p-elektronokénál. Ez annyit jelent, hogy ezeknek az elektrontípusoknak a kötési energiája a sávban nagyobb a mag által kifejtett nagyobb vonzás miatt.

Ennek következtében tömörebb szerkezetek alakulnak ki az ötvözetekben, ha a d-elektronok részvétele domináns a kötések kialakításában. Ennek megnyilvánulását láthatjuk a nagy entrópiájú ötvözetekben. Feltételezhetjük tehát, hogy az átmenetifém-kontrakció (6. ábra) lehet az elektronszerkezeti háttere az egyfázisú szerkezet stabilizálódásának, amelyet a „principális” Fe, Co, Ni elemek jelenléte biztosít a nagy entrópiájú ötvözetekben.

Feltételezhető az is, hogy mivel mindhárom principális komponens a legtömörebb fcc kristályszerkezetben kristályosodik mint szilárd oldat, nem igényel nagy túlhülést ennek a szerkezetnek a kialakulása sem, vagyis e szerkezet kialakulása a legkedvezőbb egy széles hőmérséklet-tartományban.

Mivel a főkomponensek kémiai tulajdonságaik tekintetében közel állnak, elektronegativitásuk is közel azonos. Az átmeneti fémekre jellemző sűrű

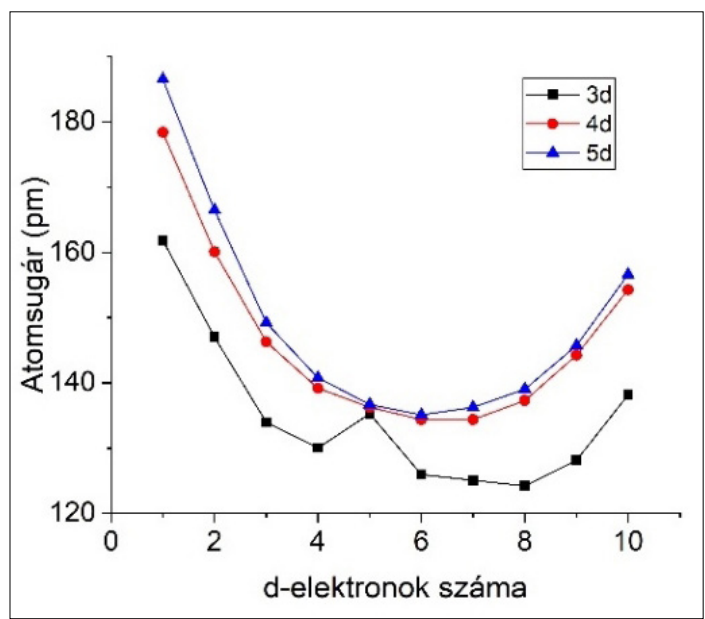

6. ábra. Az atomsugár változása átmenetifémekben a d-elektronok számának növekedésével [19] 
szerkezet (amely rendezetlen szilárd oldat) ellenére a szomszédos átmenetifém-atomok közötti kémiai kölcsönhatás nem kizárt. Ez a kölcsönhatás nem feltétlenül eredményezi az intermetallikus összetétel kialakulását. Ez a különböző szomszédos atomok közötti, nettó helyi töltéseltolódásként is megnyilvánulhat, amit a Miedema-féle formula fejez ki [20], ha két fémes komponens szilárd oldatot képez:

$$
\Delta Z_{a}=1.2 \cdot\left(1-c_{a}\right) \cdot \Delta \Phi^{*},
$$

$\Delta Z_{a}$ a töltéseltolódás két szomszédos atom között, ami kifejezi az elegyedő atomok csekély mértékű relatív méretváltozását is, $\Delta \Phi$ az elektronkilépési munka különbsége, továbbá $c_{a}$ az $a$ atom koncentrációja.

\section{Következtetések}

Két ötvözetrendszer, a tömbi formában előállított amorf ötvözetek és az egyfázisú, nagy entrópiájú ötvözetek képződési mechanizmusát és stabilitását hasonlítottuk össze.

Mindkét ötvözettípus többkomponensű olvadékból, egyetlen lépésben, megszilárdulással keletkezik.

A komponensek közötti kémiai kötések természete nagymértékben különbözik: a tömbi formában előállított amorf ötvözetekben a kötések kovalens jellege számottevő, ami miatt jelentős a klaszterképződés olvadék állapotban.

A klaszterképződés miatt az olvadék túlhűlésre hajlamos, és a megszilárdulás amorf állapotot eredményez.

A nagy entrópiájú ötvözetek olvadékai nem mutatnak túlhűlést, emiatt az olvadékból egyfázisú, kristályos, rendezetlen fcc kristályrácsú szilárd oldatok keletkeznek. Az alkotó főkomponensek tömör illeszkedésének megfelelően nagy hőmérsékleten stabil, egyfázisú fcc szerkezetek alakulnak ki. A d-elektronok részvétele a fémes kötésekben az entrópiastabilizálás mellett további stabilizáló tényezőt jelent.

\section{Köszönetnyilvánítás}

A közleményben bemutatott kutatást az Új Széchenyi Terv keretében az EFOP-3.6.2-16-2017-00016 projekt részeként hajtották végre. A projekt befejezését az Európai Unió és az Európai Szociális Alap társfinanszírozza.

A közleményben bemutatott kutatást az Új Széchenyi Terv keretében az EFOP-3.6.1-16-2016-0003 projekt részeként hajtották végre. A projekt befejezését az Európai Unió és az Európai Szociális Alap társfinanszírozza.

\section{Szakirodalmi hivatkozások}

[1] Makino A., Inoue A., Masumoto T.: Nanocrystalline soft magnetic Fe-M-B (M=Zr, Hf, Nb) alloys produced by crystallization of amorphous phase (overview). Materials Transactions, JIM, 36/7. (1995) 924-938.

https://doi.org/10.2320/matertrans1989.36.924

[2] Nagy A.: Electric aircraft-present and future. Production Engineering Archives, 23. (2019) 36-40.

[3] Luborsky F. E.: Application oriented magnetic properties. In: Amorphous Metallic Alloys (ed.: Luborsky F. E.) Butterworths Monographs in Materials, London, 1984. 360-379.

[4] Tsai M. H., Yeh J. W.: High-entropy Alloys: A Critical Review. Materials Research Letters, 2/3. (2014) 107-123.

https://doi.org/10.1080/21663831.2014.912690

[5] Inoue A.: Stabilization of Metallic Supercooled Liquid and Bulk Amorphous Alloys. Acta Materialia, 48/1. (2000) 279-306.

https://doi.org/10.1016/S1359-6454(99)00300-6

[6] Kauzman W.: The Nature of the Glassy State and the Behavior of Liquids at Low Temperatures. Chemical Reviews, 43/2. (1948) 219-256. https://doi.org/10.1021/cr60135a002

[7] Angell C. A.: Structural instability and relaxation in liquid and glassy phases near the fragile liquid limit. Journal of Non-Crystalline Solids, 102/1-3. (1988) 205-221.

https://doi.org/10.1016/0022-3093(88)90133-0

[8] Köster U., Janlewing R.: Fragility parameter and nanocrystallization of metallic glasses. Materials Science and Engineering: A, 375-377 (2004) 223-226.

https://doi.org/10.1016/j.msea.2003.10.083

[9] Inoue A.: Bulk Amorphous Alloys. In: Non-Equilibrium Processing of Materials (ed.: Suryanarayana C.) Pergamon Materials Series, Pergamon Amsterdam-Lausanne-New York, 1999. 375-415.

[10] Dimitrov V. I.: Theory of Fluidity of Liquids, Glass Transition and Melting. Journal of Non-Crystalline Solids, 352/3. (2006) 216-231.

https://doi.org/10.1016/j.jnoncrysol.2005.11.026

[11] Lovas A., Ramasamy P. Kováč J., Novák L., Szabó A., Eckert J.: Cluster-related phenomena in the properties and transformations of transition metal-based glassy alloys. Metals, 10/8. (2020) 1025. https://doi.org/10.3390/met10081025

[12] Richardson F. D.: Physical Chemistry of Melts in Metallurgy. Academic Press London, New York, 1. (1974) 142.

[13] Predel B.: Thermodynamic stability of amorphous alloys. Key Engineering Materials, 40-41. (1990) 17-38.

[14] Debenedetti P. G.: Metastable Liquids Concepts and Principles. Princeton Univ. Press, Princeton, 1996. 
[15] Debenedetti P. G., Stillinger F. H.: Supercooled liquids and the glass transition. Nature, 410/8. (2001) 259-267. https://doi.org/10.1038/35065704

[16] Zhang F., Zhang C., Chen S. L., Zhu J., Cao W. S., Kattner U.R.: An understanding of high entropy alloys from phase diagram calculations. CALPHAD, 45. (2014) 1-10.

https://doi.org/10.1016/j.calphad.2013.10.006

[17] Troparevsky M. C., Morris J. R., Daene M., Wang Y., Lupini A. R., Malcolm G.: Beyond Atomic Sizes and Hume-Rothery Rules: Understanding and
Predicting High-Entropy Alloys. JOM, 67. (2015) 2350-2363.

https://doi.org/10.1007/s11837-015-1594-2

[18] Barnard A. K., Sykes P.: Theoretical Basis of Inorganic Chemistry. New York (N.Y.): McGraw-Hill, 1965.

[19] Khandelwal B. L.: Inorganic Chemistry of Transition Elements. Disha Institute of Management and Technology, Raipur, 2007.

[20] Miedema A. R., Boom R., De Boer F. R.: On the heat of formation of solid alloys. J. Less-Common Met. 41 (1975) 275-284. 